\title{
Reconstruction of the multielement apparatus of Neogondolella ex gr. regalis Mosher, 1970 (Conodonta) from the Anisian (Middle Triassic) in British Columbia, Canada
}

\author{
Martyn Lee Golding \\ Geological Survey of Canada, 1500-605 Robson Street, Vancouver, British Columbia V6B 5J3, Canada \\ Correspondence: Martyn Lee Golding (martyn.golding@ canada.ca) \\ Published: 5 January 2018
}

\begin{abstract}
The multi-element apparatus of the Middle Triassic conodont Neogondolella ex gr. regalis has been reconstructed based on material collected from the upper Anisian in British Columbia, Canada. The apparatus of this species group is distinguished by the presence of a segminiplanate P1 element with a high, fused carina, and an alate S0 element with anterior processes that bifurcate at the cusp. This S0 element morphology is unlike those of other species from the upper Anisian of North America, but similar to those from the Lower Triassic. The new reconstruction demonstrates that Neogondolella ex gr. regalis does not belong to the genus Neogondolella, nor to any other Triassic gondolellid genus. It is therefore proposed that Neogondolella ex gr. regalis should be referred to a new genus.
\end{abstract}

\section{Introduction}

The earliest multielement reconstructions of Triassic conodonts were carried out by Huckriede (1958), who recognized recurring associations of elements in his collections from the Middle Triassic. Sweet (1970) subsequently used statistical methods to analyze associations between conodont elements and concluded that most Triassic conodont species were unimembrate, consisting of only pectiniform elements. The ramiform elements were thought to belong to separate multimembrate apparatuses. Kozur (1989) and Hirsch (1994) maintained that all Triassic conodonts were multimembrate. The discovery of fused clusters (Ramovs, 1977, 1978; Mietto, 1982; Huang et al., 2010; Goudemand et al., 2012) and natural assemblages (Rieber, 1980; Orchard and Rieber, 1999; Goudemand et al., 2011) has subsequently demonstrated that Triassic conodonts were indeed multimembrate, and both types of elements existed together in the same apparatus. Statistical reconstructions of a number of Triassic apparatuses were attempted by Kozur and Mostler (1971), Ramovs (1977), Bagnoli et al. (1985), Zhang and Yang
(1991), Hirsch (1994), Koike (1996, 1999), Orchard (2005), and Ishida and Hirsch (2011).

The description of natural assemblages of Neogondolella by Orchard and Rieber (1999) established a 15-element plan for the apparatus of this genus. Investigation of fused clusters by Goudemand et al. (2012) led to a revision of the Neogondolella apparatus by switching the position of the S1 element with the S2. As currently reconstructed, the Neogondolella apparatus contains seven paired elements (segminiplanate $\mathrm{P} 1$, angulate $\mathrm{P} 2$, dolobrate $\mathrm{S} 1$, breviform digyrate $\mathrm{S} 2$, bipennate $\mathrm{S} 3$, bipennate $\mathrm{S} 4$, and breviform digyrate $\mathrm{M}$ ) and a single alate $\mathrm{S} 0$ element. The $\mathrm{P} 1$ element is the most variable in the apparatus and is used to define species. The S3 element has a distinctive bifid anterior process, whilst the lateral processes of the S0 element diverge either at the cusp or slightly anterior of it (Orchard, 2005; Goudemand et al., 2012).

Thus far, the only species of Neogondolella to have their multielement apparatuses illustrated are $N$. constricta (Mosher and Clark, 1965), N. inclinata (Kovács, 1983), N. ex gr. subcarinata Sweet, 1973, and N. n. sp. A sensu Goudemand et al. (2012). The multielement apparatus of the type species for the genus of Neogondolella, N. mombergensis 
(Tatge, 1956), has not been illustrated; however, both types of S0 element were illustrated by Tatge (1956), and they occur together in Anisian collections of $N$. mombergensis (Orchard, 2005). The S0 element that bifurcates at the cusp is found predominantly in the Permian and Lower Triassic and occurs up to the middle Anisian (Middle Triassic). It has been suggested that species with this type of S0 element should be referred to Clarkina or Neoclarkina instead of Neogondolella (Henderson et al., 2006; Henderson and Mei, 2007); however, the apparatuses of the type species of these genera, Clarkina leveni (Kozur et al., in Kozur, 1975) and Neoclarkina discreta (Orchard and Krystyn, 1998), have not been reconstructed either. The multielement description of other species of Neogondolella is necessary to help resolve this taxonomic issue and to provide a more robust definition for the genus.

\section{Material and methods}

The recovery of large monospecific collections of Neogondolella ex gr. regalis Mosher, 1970 from the subsurface of British Columbia has facilitated the reconstruction of the apparatus of this species group for the first time; this is also the first time that a Triassic conodont apparatus has been reconstructed from subsurface material. The collections occur in two samples from the Talisman Altares 16-17-08325W6 hydrocarbon well, located to the west of Fort St. John (surface location $56.201495^{\circ} \mathrm{N}, 121.906891^{\circ} \mathrm{W}$; Fig. 1). The core from this well consists primarily of siltstone, with minor amounts of carbonate and fine sandstone belonging to the Montney and Doig formations. Multiple samples were collected from this core for conodont processing, and a detailed discussion of the sedimentology and biostratigraphy of this core is provided in Golding et al. (2014). The two samples discussed in this paper both come from the upper Anisian (Middle Triassic) part of the Doig Formation, at depths of 2238.74-2239.75 m (GSC curation no. V-002978) and 2234.10-2234.57 m (GSC curation no. V-002980) below the kelly bushing datum.

\section{Results and discussion}

Both of these samples contain pectiniform and ramiform elements of Neogondolella ex gr. regalis. Eight different element types can be recognized and related to the standard Neogondolella apparatus (Fig. 2; Table 1). The P1 elements are segminiplanate and possess a distinctive high fused carina, which is typical of $N$. ex gr. regalis. The P2 element is angulate, the $\mathrm{M}$ element is breviform digyrate, and the S1 element is dolobrate. The S2 element is breviform digyrate or "enantiognathiform", which is typical of the superfamily Gondolelloidea (Lindström, 1970). The S3 element is bipennate with a bifid anterior process, which is typical of the subfamily Neogondolellinae Hirsch, 1994. The S4 element

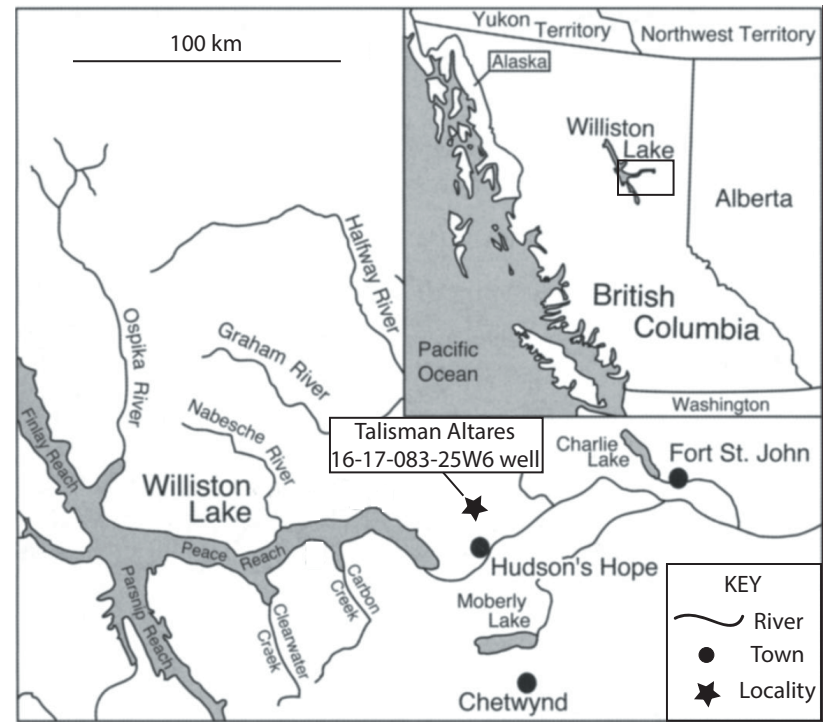

Figure 1. Map showing the location of the Talisman Altares 16-17083-25W6 well in British Columbia.

Table 1. Table of elements in Neogondolella ex gr. regalis recovered from the Talisman Altares 16-17-083-25W6 well.

\begin{tabular}{lrrr}
\hline Element & Sample V-002978 & Sample V-002980 & Total \\
\hline P1 & 28 & 242 & 270 \\
P2 & 2 & 22 & 24 \\
S1 & 1 & 15 & 16 \\
S2 & 15 & 52 & 67 \\
S3 & 1 & 0 & 1 \\
S4 & 3 & 40 & 43 \\
S0 & 4 & 17 & 21 \\
M & 2 & 29 & 31 \\
\hline Total & 56 & 407 & 473 \\
\hline
\end{tabular}

is bipennate with a single anterior process, and the S0 element is alate with bifurcation of its anterior processes at the cusp, unlike the S0 element in other species from the upper Anisian in North America but similar to those from the Lower Triassic (Orchard, 2005).

The present reconstruction extends the range of S0 elements that bifurcate at the cusp into the upper Anisian. Henderson and Mei (2007) suggested that species with this S0 element morphology should be referred to Clarkina or Neoclarkina, with species of Neogondolella having an S0 element that bifurcates anterior of the cusp. However, no associations of elements were illustrated in support of this conclusion. In the original publication of Tatge (1956), P1 elements in Neogondolella mombergensis, the type species of Neogondolella, are illustrated with both forms of S0 element. The only other P1 elements illustrated from this fauna belong to Nicoraella kockeli (Tatge, 1956), the apparatus of which has subsequently been reconstructed with an S0 element that 


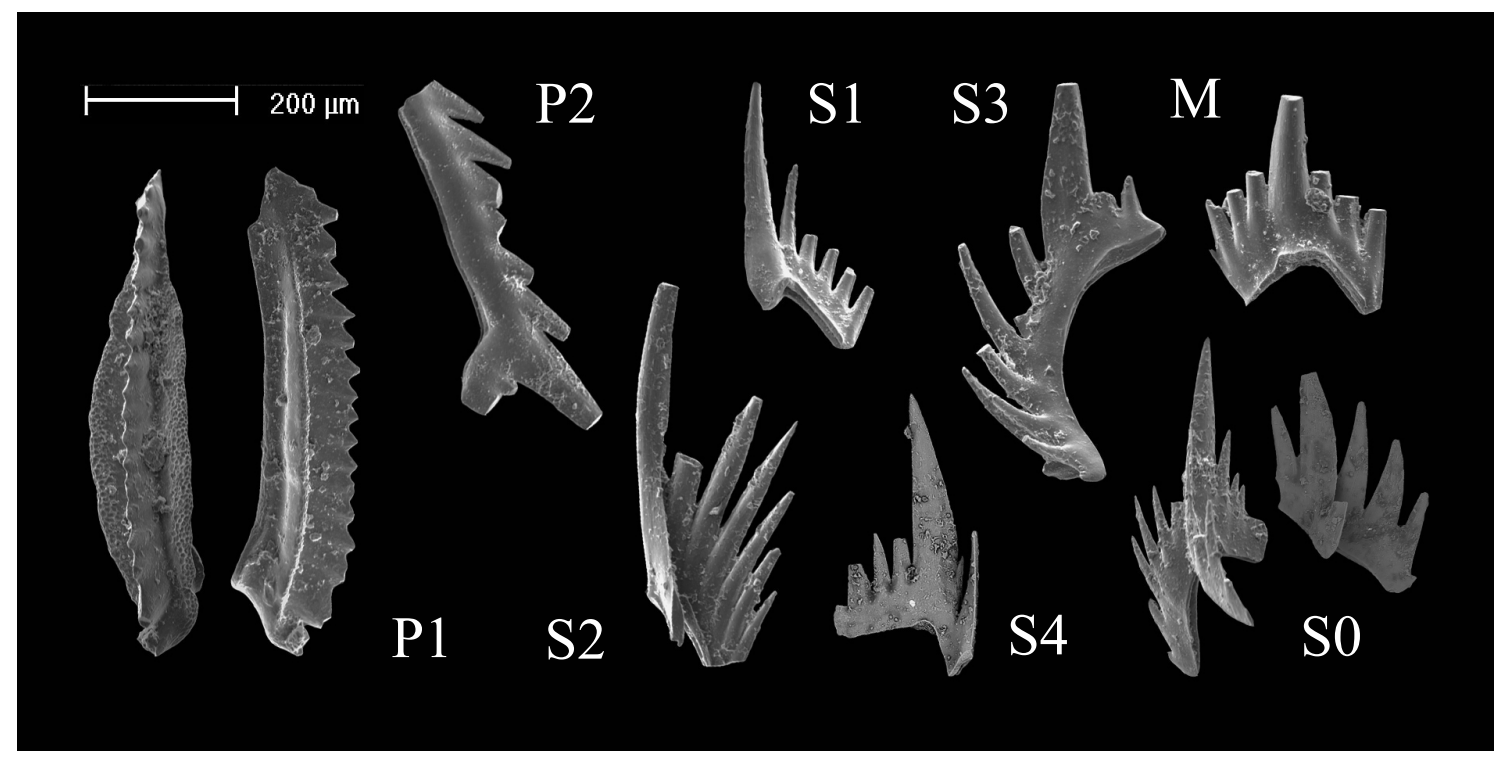

Figure 2. Negondolella ex gr. regalis Mosher. P1, GSC type no. 131563; P2, GSC type no. 131564; S0, GSC type no. 131565 and GSC type no. 131566; S1, GSC type no. 131567; S2, GSC type no. 131568; S3, GSC type no. 131569; S4, GSC type no. 131570; M, GSC type no. 131571. P1, S3, and M from sample V-002978; P2, S0, S1, S2, and S4 from sample V-002980. Both samples are from the Doig Formation, Talisman Altares 16-17-083-25W6 well.

bifurcates at the cusp (Sun et al., 2009). It is therefore possible that the S0 elements that bifurcate anterior of the cusp belong to Neogondolella as suggested by Henderson and Mei (2007). If so, this would necessitate the placement of $N$. ex gr. regalis into either Clarkina or Neoclarkina. The high carina and lack of an anterior free blade on the P1 element of $N$. ex gr. regalis precludes association with Clarkina. The genus Neoclarkina is defined by the lack of a platform on the $\mathrm{P} 1$ element at the earliest growth stages (Henderson and Mei, 2007), a growth pattern that is shared with $N$. ex gr. regalis; however, the carina of $N$. ex gr. regalis is very different to that of Neoclarkina discreta. It may be appropriate to separate this group into its own genus, which in turn would mean that the morphology of the S0 element in gondolellids has a taxonomic significance above the level of genus. Systematic work on diverse collections of $N$. ex gr. regalis from North America is ongoing in an attempt to resolve this issue.

Data availability. Illustrated specimens are housed at the National Type Collection of Invertebrate and Plant Fossils at the Geological Survey of Canada in Ottawa, Ontario, Canada.

Competing interests. The author declares no conflict of interest.

Acknowledgements. Thanks are due to John-Paul Zonneveld and Ryan Olson for help in collecting the samples, Peter Krauss for processing the samples, Mike Orchard for providing comments on an earlier version of the paper, and Charles Henderson and Giles
Miller for providing helpful reviews. Funding from Geoscience BC is gratefully acknowledged.

Edited by: Giles Miller

Reviewed by: Charles Henderson

\section{References}

Bagnoli, G., Perri, M. C., and Gandin, A.: Ladinian conodont apparatuses from northwestern Sardinia, Italy, Bolletino della Società Paleontologica Italiana, 23, 311-323, 1985.

Golding, M. L., Orchard, M. J., Zonneveld, J.-P., Henderson, C. M., and Dunn, L.: An exceptional record of the sedimentology and biostratigraphy of the Montney and Doig formations in British Columbia, B. Can. Petrol. Geol., 62, 157-176, 2014.

Goudemand, N., Orchard, M. J., Li, G., Urdy, S., Bucher, H., and Tafforeau, P.: Synchrotron-aided reconstruction of the conodont feeding apparatus and implications for the mouth of the first vertebrates, P. Natl. Acad. Sci. USA, 108, 8720-8724, 2011.

Goudemand, N., Orchard, M. J., Tafforeau, P., Urdy, S., Brühwiler, T., Brayard, A., Galfetti, T., and Bucher, H.: Early Triassic conodont clusters from South China: revision of the architecture of the 15 element apparatuses of the superfamily Gondolelloidea, Palaeontology, 55, 1021-1034, 2012.

Henderson, C. M. and Mei, S.: Geographical clines in Permian and lower Triassic gondolellids and its role in taxonomy, Palaeoworld, 16, 190-201, 2007.

Henderson, C. M., Wardlaw, B. R., and Lambert, L. L.: Multielement definition of Clarkina Kozur, Permophiles, 48, 23-24, 2006.

Hirsch, F.: Triassic conodonts as ecological and eustatic sensors, in: Pangaea: global environments and resources, Embry, A. F., 
Beauchamp, B., and Glass, D. J., Memoir of the Canadian Society of Petroleum Geologists, 17, 949-959, 1994.

Huang, J.-Y., Zhang, K.-X., Zhang, Q.-Y., Lü, T., Zhou, C.-Y., Bai, J.-K., and Hu, S.-X.: Discovery of Middle Triassic conodont clusters from Luoping Fauna, Yunnan Province, Earth Science, J. China Univ. Geosci., 35, 512-514, 2010.

Huckriede, R.: Die Conodonten der mediterranen Trias und ihr stratigraphischer Wert, Paläont. Z., 32, 141-175, 1958.

Ishida, K. and Hirsch, F.: The Triassic conodonts of the NW Malayan Kodiang Limestone revisited: taxonomy and paleogeographic significance, Gondwana Res., 19, 22-36, 2011.

Koike, T.: Skeletal apparatuses of Triassic conodonts of Cornudina, in: Professor Hisayoshi Igo Commemorative Volume, Geology and Paleontology of Japan and Southeast Asia, edited by: Noda, H. and Sashida, K., Gakujutu Tosho Publisher, Tokyo, 113-120, 1996.

Koike, T.: Apparatus of a Triassic conodont species Cratognathodus multihamatus (Huckriede), Paleontol. Res., 3, 234-248, 1999.

Kovács, S.: On the evolution of excelsa-stock in the upper LadinianCarnian (Conodonta, Genus Gondolella, Triassic), New Contributions to the Biostratigraphy of the Tethyan Triassic, 5, 107120, 1983.

Kozur, H.: Significance of events in conodont evolution for Permian and Triassic stratigraphy, Cour. For. Senckenbg., 117, 385-408, 1989.

Kozur, H. and Mostler, H.: Probleme der Conodontenforschung in der Trias, Geologisch-Paläontologische Mitteilungen Innsbruck, 1, 1-19, 1971.

Kozur, H.: Beitrage zur Conodontenfauna des Perm, Geologsiche Paläontologische Mitteilungen Innsbruck, 5, 1-41, 1975.

Lindström, M.: A suprageneric taxonomy of the conodonts, Lethaia, 3, 427-445, 1970.

Mietto, P.: A Ladinian conodont-cluster of Metapolygnathus mungoensis (Diebel) from Trento area (NE Italy), Neues Jahrbuch für Geologie und Paläontologie, Monatshefte, 1982, 600-606, 1982.

Mosher, L. C.: New conodont species as Triassic guide fossils, J. Paleontol., 44, 737-742, 1970.

Mosher, L. C. and Clark, D. L.: Middle Triassic conodonts from the Prida Formation of northwestern Nevada, J. Paleontol., 39, 551-565, 1965.
Orchard, M. J.: Multielement conodont apparatuses of Triassic Gondolelloidea, in: Conodont biology and phylogeny: interpreting the fossil record, edited by: Purnell, M. A. and Donoghue, P. C. J., Special Papers in Palaeontology, 73, 73-101, 2005.

Orchard, M. J. and Krystyn, L.: Conodonts of the Lowermost Triassic of Spiti, and new zonation based on Neogondolella successions, Riv. Ital. Paleontol. S., 104, 341-368, 1998.

Orchard, M. J. and Rieber, H.: Multielement Neogondolella (Conodonta, upper Permian - middle Triassic), Bolletino della Società Paleontologica Italiana, 37, 475-488, 1999.

Ramovs, A.: Skelettapparat von Pseudofurnishius murcianus (Conodontophorida) im Mitteltrias Sloweniens (NW Jugoslawien), Neues Jahrbuch für Geologie und Paläontologie, Abhandlungen, 153, 361-399, 1977.

Ramovs, A.: Mitteltriassiche Conodonten-clusters in Slowenien, NW Jugoslawien, Paläontol. Z., 52, 129-137, 1978.

Rieber, H.: Ein Conodontencluster aus der Grenzbitumenzone (Mittlere Trias) des Monte San Giorgio, Annalen des Naturhistorischen Museum in Wien, 83, 265-274, 1980.

Sun, Z., Hao, W., Sun, Y., and Jiang, D.: The conodont genus Nicoraella and a new species from the Anisian of Guizhou, South China, Neues Jahrb. Geol. P.-A., 252, 227-235, 2009.

Sweet, W. C.: Uppermost Permian and Lower Triassic conodonts of the Salt Range and Trans-Indus ranges, West Pakistan, in: Stratigraphic boundary problems: Permian and Triassic of West Pakistan, edited by: Kummel, B. and Teichert, C., The Unviersity Press of Kansas, Lawrence, 207-275, 1970.

Sweet, W. C., in Teichert, C., Kummel, B., and Sweet, W. C.: Permian-Triassic strata, Kuh-e-Ali Bashi, northwestern Iran, Bulletin of the Museum of Comparative Zoology, 145, 359-472, 1973.

Tatge, U.: Conodonten aus dem germanischen Muschelkalk, Paläontol. Z., 30, 108-147, 1956.

Zhang, S. and Yang, Z.: On multielement taxonomy of the Early Triassic conodonts, Stratigraphy and Paleontology of China, 1, 17-47, 1991. 